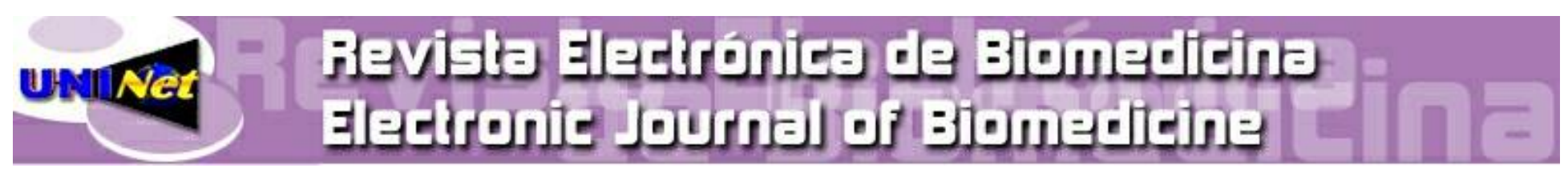

ISSN: 1697-090X

Inicio Home

Indice del

volumen Volume

index

Comité Editorial

Editorial Board

Comité Científico

Scientific

Committee

Normas para los

autores

Instruction to

Authors

Derechos de autor

Copyright

\section{OBSTRUCTIVE NEPHROPATHY: ITS PHYSIOPATHOLOGY}

\author{
Carlos G. Musso1,2, Matilde Navarro1, Ricardo Jauregui1,2
}

${ }^{1}$ Renal Physiology Section. Nephrology Division. Hospital Italiano de Buenos Aires.

${ }^{2}$ Hospital Italiano de San Justo Agustín Rocca

Buenos Aires. Argentina

carlos.musso@ hospitalitaliano.org.ar

Rev Electron Biomed / Electron J Biomed 2011;2: 57-61.

Version española

Comment of the reviewer Abdias Hurtado Arestegui MD.. Servicio de Nefrología Hospital Nacional Arzobispo Loayza.

Universidad Peruana Cayetano Heredia. Lima. Peru

Comment of the reviewer Jesus Garrido MD. Responsável pelo Sector de Hemodiálise. Unidade de Nefrologia e Diálise, Hospital de São Teotónio, Viseu - Portugal. Director Clínico. Diaverum-Unidade da Régua. Peso da Régua. Portugal.

\title{
Versión en Español
}

\section{SUMMARY:}

Obstructive nephropathy is the functional and /or parenchymal renal damage secondary to the urinary tract occlusion at any part of it. The inducing urinary obstruction diseases can vary depending on the patient's age and gender.

There are many renal dysfunction inducing mechanisms involved in this entity: increase in the intra-luminal pressure, ureteral dilatation with ineffective ureteral peristalsis, glomerular ultrafiltration net pressure reduction, intra-renal glomerular blood flux reduction due to vasoconstriction, and local disease of chemotactic substances. Obstructive nephropathy can also lead to hypertension (vasoconstriction-hypervolemia), hyperkalemia, metabolic acidosis (aldosterone resistance), diabetes insipidus (vasopressine resistance).

In conclusion, since obstructive nephropathy is a potentially reversible cause of renal dysfunction, it should always be taken into account among the differential diagnosis of renal failure inducing mechanisms.

KEYWORDS: Obstructive nephropathy. Renal dysfunction. Physiopathology.

RESUMEN:

Por nefropatía obstructiva se entiende el daño funcional y/o parenquimatoso renal secundario a la obstrucción del tracto urinario en cualquier sector de su longitud. Las entidades que conducen a la misma varían según la edad y el género del 
paciente.

Fisiopatológicamente, son varios los mecanismos que llevan al compromiso de la función renal en este disturbio: aumento de la presión intraluminal, dilatación ureteral y en consecuencia peristalsis ureteral inefectiva y oposición a la presión neta de ultrafiltración glomerular, vasoconstricción intrarenal con la consiguiente reducción en el flujo sanguíneo glomerular, liberación de sustancias quimiotácticas que atraen monocitos y macrófogos que liberan localmente proteasas y radicales libres. Durante una uro-obstrucción puede además desencadenarse hipertensión arterial (vasocontricción-hipervolemia), hiperkalemia, acidosis metabólica (resistencia a la aldosterona) y diabetes insípida (resistencia a la vasopresina).

Concluimos que la uropatía obstructiva es un mecanismo de insuficiencia renal, que dada su relativa simplicidad para ser resuelto, debe ser siempre tenido en cuenta entre los diagnósticos diferenciales del fracaso renal.

PALABRAS CLAVE: Nefropatía obstructiva. Insuficiencia renal. Fisiopatología.

Introduction:

Obstructive nephropathy is the functional and/or renal parenchymatous damage secondary to the obstruction of the urinary tract in any sector along its length and which can be the potential cause of acute as well as chronic renal failure. In the same way, when such obstruction is located in any point between the renal pelvis and the distal end of the urethra, it receives the more specific name of obstructive uropathy. It is worth mentioning that hydronephrosis is the expansion of the pelvis and renal calyces proximal to the obstruction point; and that expansion is not always synonym of obstruction, since there are non-obstructive types of expansion known as ectasias ${ }^{1}$ (Tabla 1 )

Tabla 1: Epidemiología de la Obstrucción Urinaria

\begin{tabular}{|c|c|}
\hline Edad/Genero & Causa más frecuente \\
\hline neonato & valva de uretra posterior \\
\hline infante & estenosis urétero-piélica (congénita) \\
\hline adulto/a & litiasis renal \\
\hline adulta joven & embarazo \\
\hline adulta mayor / anciana ( $\geq 65$ años) & cáncer ginecológico \\
\hline anciano ( $\geq 65$ años) & $\begin{array}{l}\text { hiperplasia prostática benigna } \\
\text { cáncer prostático }\end{array}$ \\
\hline
\end{tabular}

Physiopatology ${ }^{2-4}$ :

The obstruction of the urinary flow can take place inside the renal tubules as well as in any other segment of the urinary tract (renal pelvis, ureter, bladder and urethra). Independently of the place where the urinary obstruction happens, and from this moment, a series of events start to happen, which if they are not corrected can lead, in time, to irreversible renal damage and tubular atrophy. After an obstruction has settled, there is an increase in the pressure corresponding to its proximal section, due to the effect of the net glomerular filtration pressure, which leads to an increase in intraluminal pressure, that carries a progressive expansion of the ureter as a compensating mechanism (ley de la Lapace), thus the significant difference of pressure between the ureter in a state of contraction and at rest is reduced, resulting in an ineffective ureteral peristalsis. Sometimes there is a rapture of the renal calices with the subsequent formation of urinomas.

On the other hand, such pressure is transmitted to the tubular sectors proximal to the obstruction causing a reduction of the glomerular filtration since it counteracts to the glomerular filtration net pressure. In this sense, it should be taken into consideration that the glomerular filtration is the result of a game of pressures which are established in the glomerular capillaries and the Bowman capsule, where in favor of the filtration we find the hydrostatic pressure of the capillary (very important) and the oncotic pressure of the Bowman capsule (minimum), while against it we find the oncotic pressure of the capillary (considerable) and the hydrostatic pressure of the Bowman capsule (minimum). Usually glomerular hydrostatic pressure is largely predominant, on whom the net ultrafiltration pressure depends almost completely. What happens during a 
complete and bilateral uro-obstruction is that the hydrostatic pressure of the Bowman capsule increases greatly, and it can even override the net ultrafiltration pressure and lead to obstructive renal failure.

On the other hand, the above mentioned increase in intratubular pressure initially induces the release of vasodilating prostaglandins which dilate the afferent arteriole thus incrementing the renal flow by $40 \%$. Nevertheless, if the obstruction is sustained in time, it leads to intrarenal vasoconstriction with the subsequent reduction in the glomerular blood flow. This phenomenon could be mediated by the release of angiotensin II and tromboxane by the obstructed nephrons. The consequence of this last phenomenon is that it avoids the perfusion of the non-functioning nephrones by means of the redistribution of flow towards those who are functioning.

In the case of severe and prolonged urinary obstructions, the renal parenchyma is reduced to a thin ring of atrophic tissue mainly as a consequence of the ischemia suffered by its continuous hyperfusion. It is also stated that the damaged tubules release a chemotactic substance which would attract monocytes and macrophagues, which would infiltrate the renal parenchyma, damaging it by means of the local release of proteases and free radicals.

An uro-obstruction can also cause hypertension which at its first stage in general is mediated by the activation of the renineangiotensin-aldosterone system (vasoconstriction) and later, if a total obstruction occurs it is mainly due to water and salt retention (hypervolemia). Likewise, the urinary obstruction can lead to a dysfunction of the distal nephron sectors (resistance to aldosterone and vasopresin), making it difficult for the local secretion of potassium and protons, as well as reducing the water reabsorption, thus facilitating the development of hyperkalemia, hyperchloremic metabolic acidosis and nephrogenic diabetes insipidus, respectively. The latter causes polyuria which is characteristic of partial obstructive uropathy. In the case of intratubular obstructions (uric acid, pigments, etc.), to the physiopathological phenomena described above it is necessary to add the fact that these toxic substances also generate local tubular damage of the toxic-ischemic type by favouring the local formation of free radicals and vasoconstriction.

Regarding the urinary obstruction mechanisms, it is possible to divide them into those which are intra-renal (intratubular) and those which are extra-renal. The latter can be subdivided into those which have intrinsic and extrinsic causes to the urinary tract 5-6:

- Extrinsic or by external compression of the urinary tract

- tumors / retroperitoneal adenomegaly (ureteral compromise)

- retroperitoneal fibrosis (compromiso ureteral): aneurism of the abdominal aorta, Crohn's disease.

- prostatic neoplasia: hyperplasia (compression of the prostatic urethra), carcinoma (ureteral compromiso due to infiltration of the trígono vesical)

- gynecological pathology: neoplasia, prolapse, endometrosis

- inadvertent surgical ureteral binding

- oIntrinsic or inherent to the urinary tract:

- a. Intraluminal: urinary calculus (pelvis and/or ureter), clots, papillary necrosis, fungal ball.

- b. Intra-mural: condition of the ureteral soft muscle, it can be

- functional: illness (diabetes mellitus, parkinsons, spinal medullary lesion, etc.), drugs (anticholinergic, levo-dopa)

- structural: tuberculosis, ureteral narrowness/urethral, neoplasia

Urinary desobstruction: fisiopathology and consequences ${ }^{7}$ :

Data obtained from tests performed in animal models and information obtained from the evolution of clinical cases, suggest that the resolution of a complete obstruction before 8 -14 weeks after it has settled can achieve a total recovery of the glomerular filtration. A later resolution can mean partial or nule recovery, depending on the evolution time of the obstruction, the age of the patient and the degree of damage to the renal function previous to the obstruction.

After the resolution of a bilateral obstruction or a unilateral one in a patient with only one kidney, it is normal to find elevated serum levels of atrial factors, tubular resistance to vasopressin (reduction of the expression of aquaporin 2 channels in the collecting tubules and compromise of the medullar tonicity), decrease in the tubular reabsorption capacity of sodium and urea and presence of a free urinary tract, so the osmotic diuretic effect of the not reabsorbed urea and sodium starts to act, which increment diuresis finally leading to potassium, calcium, magnesium and phosphorus expoliation, which puts the patient at risk of having severe hydroelectrolytic depletion if these losses are not adequately monitored and treated. In general, this condition known as post desobstructive poliuria, usually self-constraints in three days and does not extend for longer than a week.

Conclusion:

Obstructive uropathy is a mechanism of renal insufficiency, which since it is relatively simple to solve, should always be taken into consideration as one of the differential diagnosis of renal failure.

\section{REFERENCES}

1.- Clarkson M, Magee C, Brenner B. Obstructive nephropathy. In Clarkson M, Magee C, Brenner B (Eds.). Brenner \& Rector. The Kidney. Philadelphia. Saunders. 2010: 332-344 
2.- Rennke H, Denker B. Tubulointerstitial diseases. In Rennke H, Denker B (Eds.) Renal pathophysiology. The essentials. Philadelphia. Lippincott Williams \& Wilkins. 2007: 337-360

3.- Alivizatos G, Skolarikos A. Obstructive uropathy and benign prostatic hyperplasia. In Macías Núñez J, Cameron S, Oreopoulos D (Eds.) The aging kidney in health and disease. New York. Springer. 2008: 257-272

4.- Sorensen M, Stoller M. Obstructive uropathy. En Lerma E, Nissenson A (Eds.). Nephrology secrets. Elsevier Mosby. 2012: 119-122

5.- Vela Navarrete R. El riñón dilatado. Barcelona. Masson. 2001

6.- Klahr S. Urinary tract obstruction. In Schrier R (Ed.). Disease of the kidney \& urinary tract. Philadelphia. Kluwer. Lippincott Williams \& Wilkins. 2007: 689-716

7.- Vela Navarrete R. Uropatía obstructiva. En Hernando Avendaño L. (Eds.) Nefrología clínica. Buenos Aires. Panamericana. 2009: 544-564

\section{CORRESPONDENCE:}

Carlos G. Musso

Sección Fisiología Clínica Renal. Servicio de Nefrología y Medio Interno.

Hospital Italiano de Buenos Aires.

Buenos Aires. Argentina

Email: carlos.musso @ hospitalitaliano.org.ar

Comment of the reviewer Abdias Hurtado Arestegui MD. Servicio de Nefrología Hospital Nacional Arzobispo Loayza. Universidad Peruana Cayetano Heredia. Lima. Peru

El trabajo de revisión de Musso y colaboradores sobre la fisiopatología del daño renal por obstrucción de las vías urinarias (OVU), nos señala los diferentes mecanismos patogénicos que se observan en esta situación, resultantes del incremento de la presión hidrostática a nivel del aparato urinario y sus consecuencias (dilatación ureteral, peristalsis ureteral inefectiva, oposición a la presión de ultrafiltración glomerular, vasoconstricción intrarenal).

La OVU es una causa importante de insuficiencia renal en niños y en ancianos, la nefropatía inducida por la OVU se asocia con una temprana sobre regulación del sistema renina-angiotensina intrarrenal y vasoconstricción renal $^{1}$, aumento del volumen intersticial debido a la deposición de matriz y la infiltración de monocitos ${ }^{2}$. El estimulo mecánico inducido por la OVU, inducen una serie de respuestas celulares caracterizadas por: a) una mayor expresión del factor de crecimiento transformante $\beta_{1 \text { (TGF }}$ $\beta$ 1) en las células epiteliales renales, lo que induce transición epitelial mesenquimal y fibrosis tubulointersticial mediada por la activación de Smad $3^{3}$, b) activación de apoptosis tubular mediadas por caspasas ${ }^{4}$, c) Inducción del factor nuclear kappa $B^{5}$, estas respuestas celulares y otras que se encuentran en estudio, determinan un medio favorable para la inflamación y la fibrosis, que conduce en estados más avanzados a la glomeruloesclerosis y fibrosis tubulointersticial ${ }^{6}$.

Es importante reconocer que el conocimiento de las alteraciones fisiopatológicas que se observan en la OVU, no es completo y representa un campo para la investigación, en particular el estudio de biomarcadores de progresión de la enfermedad que permitan un abordaje terapéutico.

\section{REFERENCIAS}

1. Chevalier RL and Cachat F. Role of angiotensin II in chronic ureteral obstruction. In The Renin-Angiotensin System and Progression of Renal Diseases. Ed. Wolf G. Basel: Karger. 2001: 250-260.

2. Klahr S, Morrissey J.: Obstructive nephropathy and renal fibrosis: The role of bone morphogenic protein-7 and hepatocyte growth factor. Kidney Int Suppl. 2003; (87): S105-12

3. Sato M, Muragaki Y, Saika S, et al. Targeted disruption of TGF-beta1/Smad3 signaling protects against renal tubulointerstitial fibrosis induced by unilateral ureteral obstruction. J Clin Invest 2003;112: 1486-1494.

4. Nguyen HT, Hsieh MH, Gaborro A, et al. JNK/SAPK and p38 SAPK-2 mediate mechanical stretchinduced apoptosis via caspase-3 and -9 in NRK-52E renal epithelial cells. Nephron Exp Nephrol 2006; 102: e49-61.

5. Broadbelt NV, Chen J, Silver RB, et al. Pressure activates epidermal growth factor receptor leading to the induction of iNOS via NF\{kappa\}B and STAT3 in human proximal tubule cells. Am J Physiol Renal Physiol 2009; 297:F114-24.

6. Rohatgi R, Flores D: Intratubular hydrodynamic forces influence tubulointerstitial fibrosis in the kidney. Curr Opin Nephrol Hypertens 2010; 19: 65-71. 
Musso et al, presentan en este trabajo, una revisión simple y práctica de la etiología y mecanismos de lesión renal (aguda y crónica) de una patología tan frecuente como la nefropatía obstructiva y cuyo diagnóstico diferencial es fundamental en el abordaje diagnóstico inicial de la insuficiencia renal.

Aunque los mecanismos de esta lesión renal no estén perfectamente definidos, Musso et al nos ofrecen una aproximación fisiopatológica que ayuda a entender fácilmente como estos mecanismos de presión, inflamación e isquemia, contribuyen para la lesión túbulo-intersticial de la insuficiencia renal aguda y crónica en la patología obstructiva.

La diferente evolución de ciertos casos clínicos, e especialmente aquellos con recuperación parcial de la función renal tras periodos prolongados de tratamiento substitutivo, hacen necesaria la continuación de la investigación para entender mejor la fisiopatología de la nefropatía obstructiva.

Received, October 3, 2011.

Published, October 8, 2011 